\title{
Assessment of Energy Potential and Benefit under the Ground Source Heat Pump Air Conditioning System in Anqing Area of Eastern China
}

\author{
Qing Zhang, Yunfeng Li, Jian Hua $\mathbb{D}^{D}$, Xiaonan Niu, Lili Hou, Zongfang Chen, \\ and Weiya Ge $\mathbb{D}$ \\ Nanjing Geological Survey Center, China Geological Survey, Nanjing 210000, China \\ Correspondence should be addressed to Jian Hua; jianhua_cgs@163.com and Weiya Ge; 391743801@qq.com
}

Received 15 June 2021; Revised 20 August 2021; Accepted 7 October 2021; Published 9 November 2021

Academic Editor: Martina Zucchi

Copyright (C) 2021 Qing Zhang et al. This is an open access article distributed under the Creative Commons Attribution License, which permits unrestricted use, distribution, and reproduction in any medium, provided the original work is properly cited.

\begin{abstract}
Now ground source heat pump is a more efficient way to develop and utilize shallow geothermal energy because it is clean and environmentally friendly and has a relatively low energy cost. In order to optimize the planning layout and geographical space development in the eastern new town of Anqing city, which can realize the transformation and upgrading of real space and urban sustainable development, the exploration for shallow geothermal energy will be carried out in this area, so as to find out the comprehensive thermophysical parameters of the shallow rock-soil body and the heat transfer capacity of the vertical heat exchanger, etc. This paper takes the $\mathrm{CBD}$ in the eastern new town of Anqing as an example to provide the basis for the feasibility construction of the ground source heat pump project in the study area and evaluate the economic and environmental benefits of the expected project. According to the simulation test data of 5 working conditions of 4 geothermal exploration holes in the study area, we can clearly know that the energy cost per square meter of the ground source heat pump is 11.8 yuan for a building of one hundred thousand square meters in which the heat removal power is expected to be $9481 \mathrm{~kW}$ in summer and $3070 \mathrm{~kW}$ in winter. And the annual emission of carbon dioxide, sulfur dioxide, nitrogen oxides, suspended dust, and other air pollutants to the atmosphere can be reduced by $1442.5 \mathrm{t}$, and the solid waste ash and slag can be reduced by $59.7 \mathrm{t}$. The annual environmental treatment cost will be saved by 166000 yuan.
\end{abstract}

\section{Introduction}

Geothermal is a clean and renewable resource, which can be used as an effective substitute for fossil fuels [1]. Among the various technologies and methods that can be used to obtain geothermal energy, ground source heat pump (GSHP) system is considered an efficient and main means [2].

The concept of "ground source heat pump" was first put forward by Swiss experts in 1912, and this technology was first put forward in Britain and the United States. Nordic countries mainly focus on winter heating, while the United States focuses on combined winter and summer heating. In recent years, the application of ground source heat pump technology for heating in China has been favored, and the application of ground source heat pump system in 2016 has been nearly six times larger than that in $2007[3,4]$.
Ground source heat pump system is considered an efficient geothermal energy acquisition technology because of its high efficiency and low operating cost, but its high initial cost limits the development of this technology. Many scholars have done a lot of research work on the ground source heat pump system in consideration of the performance $[5,6]$ and economy [7]. In terms of the performance of the ground source heat pump, Nouri et al. [8] suggested the vacuum tube collector and VGHP should be combined to meet the heating, cooling, and hot water demand of a residential building in Tabriz. Balbay and Esen $[9,10]$ carried out a preliminary feasibility study on the application of VGHP in snow melting of pavement and bridge deck for the first time. The results show that the snow on the pavement and bridge deck is effectively melted. For the economy of ground source heat pump, Esen et al. [5] reported the comparison 


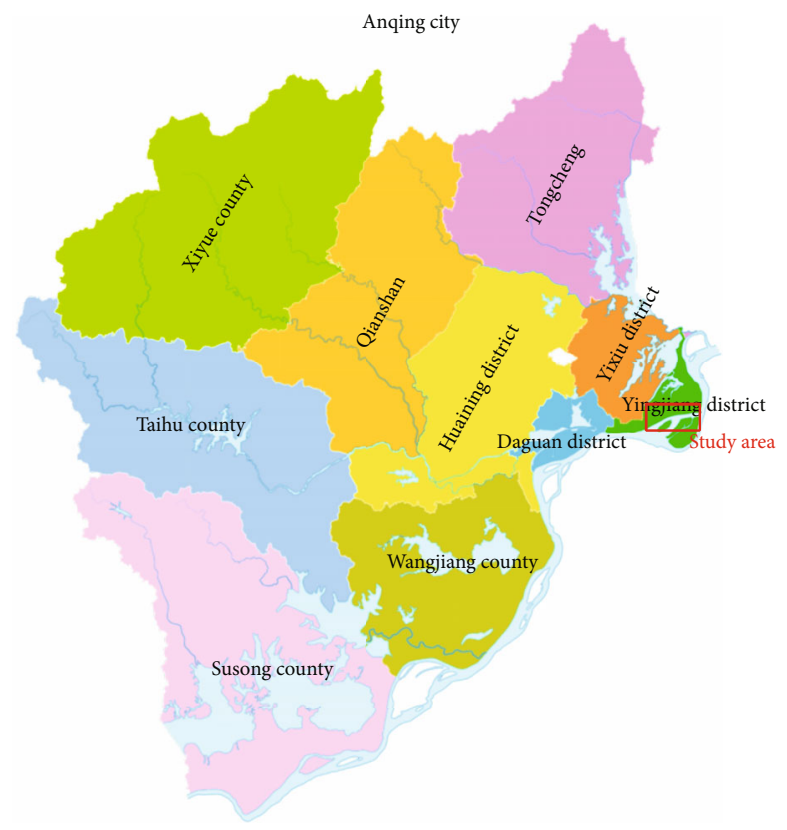

FIGURE 1: Geographical location and general situation of the study area.

192K11 bare log

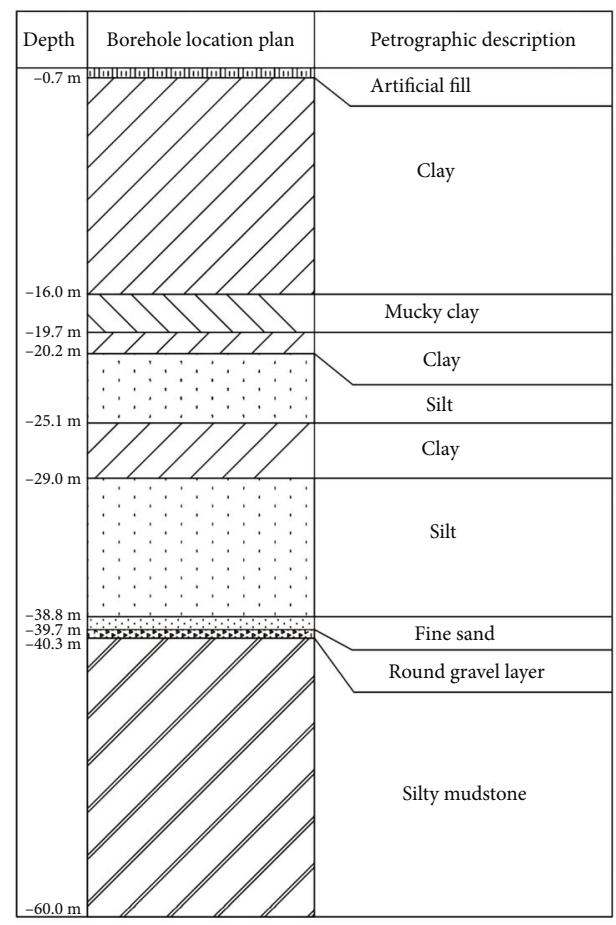

192K12 bare log

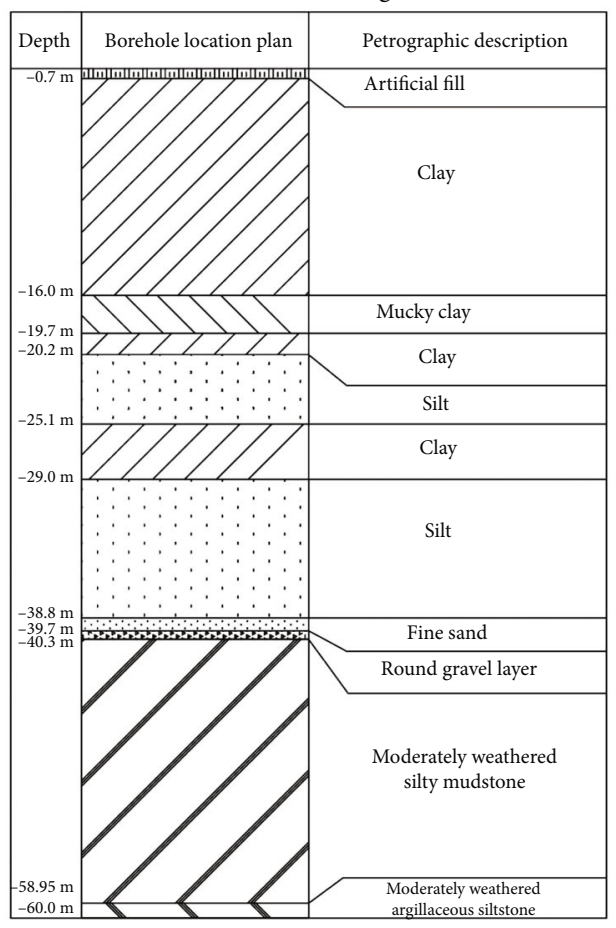

Figure 2: General situation of strata in the study area.

between ground source heat pump system and ACHP system from the perspective of technology and economy. Lu et al. [11] used some economic indicators to compare the financial attractiveness of GSHP and ASHP in residential heating and cooling in Melbourne, and the results showed that the ground source heat pump system provided more benefits than the ASHP system for systems with more than
40 years of operation. Ground source heat pump system can extract geothermal energy for building heating and cooling. Compared with the traditional air-water heat pump (AWHP) and air-air heat pump (AAHP) system, the thermal performance of ground source heat pump system is usually higher, because the ground temperature is higher than the ambient air temperature in the heating season and lower 


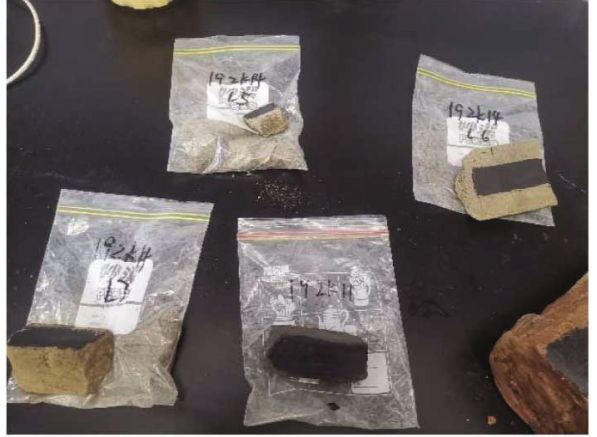

(a)

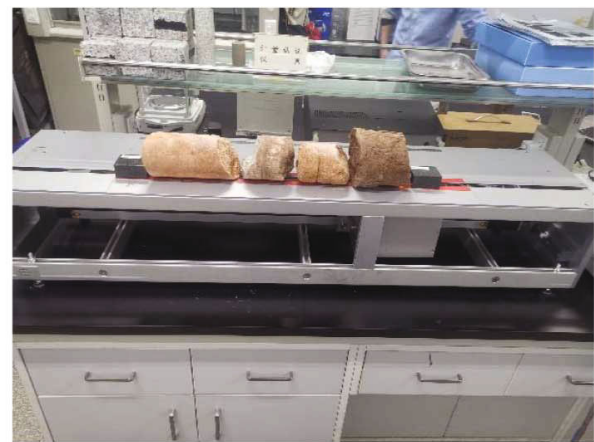

(b)

FIGURE 3: Core drilling of K11 and K14 (a) and testing process (b).

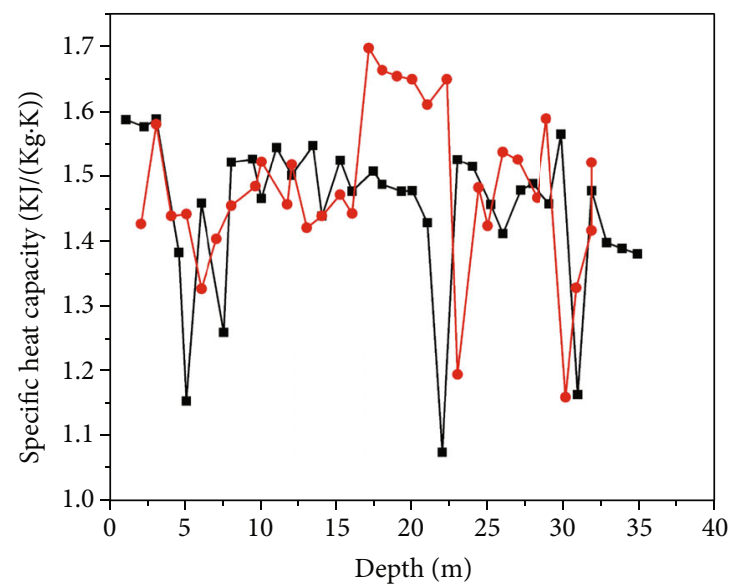

(a)

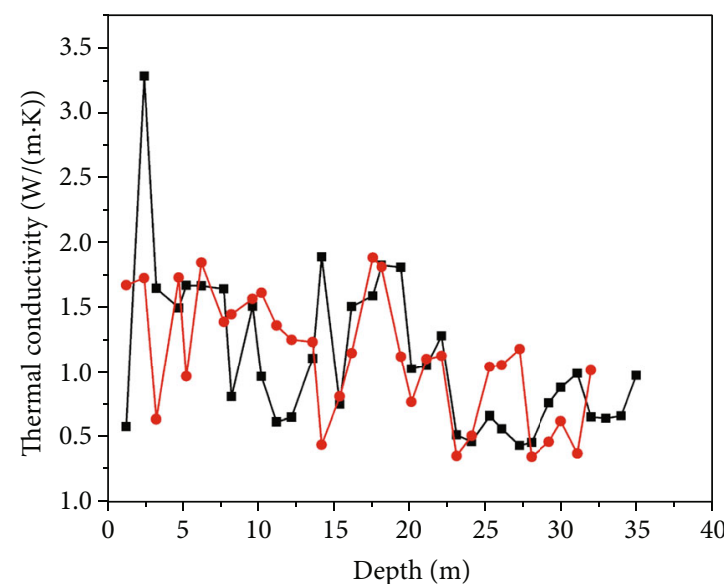

(b)

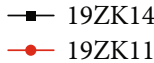

FIGURE 4: Variation curve of specific heat capacity (a) and thermal conductivity (b) of the rock-soil body around K11 and K14 with depth.

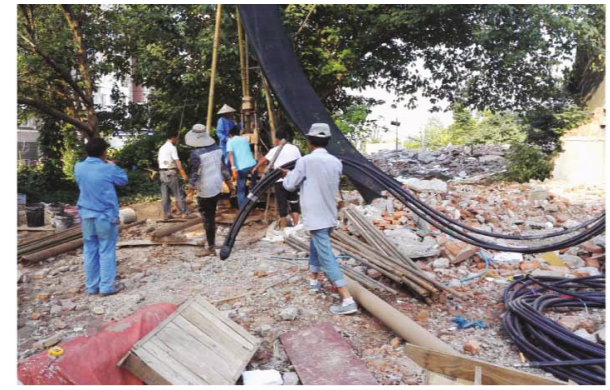

FIGURE 5: Installation of vertical heat exchanger.

than the ambient air temperature in the cooling season [12]. The ground source heat pump (GSHP) is a central heating and air conditioning system, which is composed of a water ground source heat pump unit, geothermal energy exchange system, and building system, with the rock-soil body, stratum soil, groundwater, or surface water as a low-temperature heat source. Therefore, it is very important to accurately grasp the thermal conductivity and other parameters of the heat source in situ for the evaluation and construction of a long-term effective operation geothermal heat pump system.

Shallow geothermal energy investigation and ground source heat pump suitability zoning research have been carried out in many cities in China [13, 14]. However, due to the differences in geotechnical conditions, groundwater conditions, and climatic conditions in different regions, the resource characteristics of different regions have their unique characteristics $[15,16]$. Moreover, the research content mostly focuses on the distribution characteristics of shallow geothermal resources, and the research on environmental benefit evaluation is less $[17,18]$. In this paper, the self-developed equipment called FTPT11 for field thermal response test was used in the four geothermal wells, carrying out the simulation test of five working conditions, including the initial mean ground temperature test (case 1), high-power constant heat flux test (case 2), low-power constant heat flux test (case 3), simulated constant temperature test in summer (case 4), and simulated constant temperature test in winter (case 5). In this way, the development potential of shallow geothermal energy will be analyzed and calculated. What is more, the economic and environmental benefits of the proposed ground source heat 


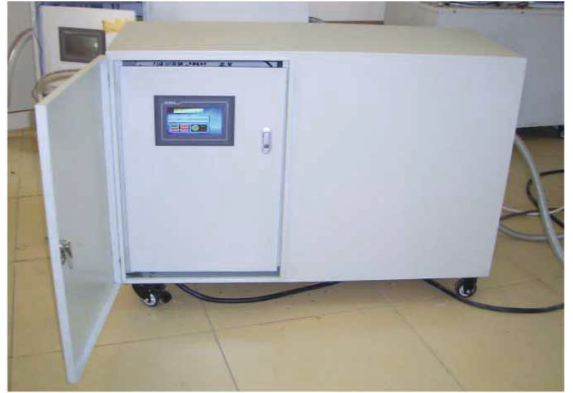

(a)

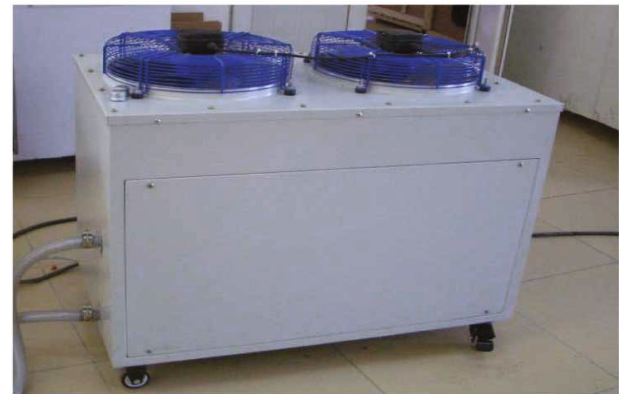

(b)

Figure 6: Main machine (a) and refrigeration auxiliary machine (b).

TABle 1: Performance parameters of test equipment.

\begin{tabular}{|c|c|c|c|c|c|}
\hline Equipment model & Maximum heating capacity & Maximum cooling capacity & Maximum power & Circulating water flow & Range \\
\hline FTPT11 & $8 \mathrm{~kW}$ & $7 \mathrm{~kW}$ & $12 \mathrm{~kW}$ & $1.8 \mathrm{~m}^{3} / \mathrm{h}$ & $10 \mathrm{~m}$ \\
\hline
\end{tabular}

pump system may be evaluated to provide a reference for later engineering construction.

\section{Summary}

2.1. Project Summary. The study area is located in the central business district (CBD) of the eastern new town of Anqing City, Anhui Province, Southeast China, with a total area of 1812 mu, as shown in Figure 1. Anqing is located in the middle and low latitudes with four distinct seasons. It is hot in summer and cold in winter. In order to realize the sustainable development of the new urban area, it is planned to make large-scale use of "ground source heat pump air conditioning" technology to reduce the proportion of fossil fuels used in the new urban area.

At present, there are four geothermal exploration boreholes in the study area, namely, 192k11, 192k12, 192k13, and 192k14. A large number of field tests and laboratory tests were carried out to obtain the formation parameters and geothermal distribution characteristics in the study area, so as to study the potential of vertical buried pipe heat exchange system.

2.2. Stratigraphic System. The strata in Anqing city are divided into two stratigraphic areas by the Tan Lu fault. The Dabie Mountains stratigraphic area is in the northwest while the Anqing stratigraphic area is in the southeast. The former consists of the metamorphic rocks of the Dabie Mountains group, Upper Archean, the metamorphic rocks of the Foziling group, Lower Proterozoic, and the middle basic volcanic rocks of the Upper Jurassic of the Mesozoic. The total thickness of the latter strata is more than $12000 \mathrm{~m}$, but the outcrop is not good. It is sporadically distributed in Silurian, Devonian, Carboniferous, Permian, Triassic, Jurassic, Cretaceous, and tertiary. The Quaternary strata are widely distributed; the lithologic characteristics are shown in Figure 2.

The rock of the Xuannan group, Upper Cretaceous $(\mathrm{K} 2 \mathrm{x})$, is purple-red; it covers medium-thick conglomerate, fine conglomerate, gravel bearing coarse sandstone, and argillaceous siltstone, which are interbedded. The gravel grain size is $1-50 \mathrm{~mm}$, with general sorting and roundness. The gravels have a bedding structure and are arranged along the dip direction.

In this study, cores of K11 and K14 geothermal holes were obtained for laboratory tests and analysis (Figure 3). The results show that the average thermal conductivity of the hole $\mathrm{K} 11$ is $1.104 \sim 1.997 \mathrm{~W} /(\mathrm{m} \cdot \mathrm{K})$, and the average specific heat capacity is $0.95 \sim 1.697 \mathrm{~kJ} /(\mathrm{kg} \cdot \mathrm{K})$, while the average thermal conductivity of the hole $\mathrm{K} 14$ is $1.107 \sim 1.755 \mathrm{~W} /(\mathrm{m} \cdot \mathrm{K})$, and the average specific heat capacity is $1.074 \sim 1.589 \mathrm{~kJ} /(\mathrm{kg} \cdot \mathrm{K})$. On the whole, except for a few points, the specific heat capacity of the rock-soil body in the range of drilling depth has little change with depth, and the thermal conductivity has no obvious change with depth (Figure 4). Furthermore, due to the fact that holes K11 and K12 are near while holes K13 and K14 are near, the lithology of the stratum is consistent. Therefore, the average thermal conductivity of the whole hole section calculated by thickness weighting in the study area is about $1.575 \mathrm{~W} /(\mathrm{m} \cdot \mathrm{K})$, which is suitable for geothermal exploitation.

\section{Thermal Response Test}

3.1. Installation of Vertical Heat Exchanger. Four groups of vertical heat exchangers were arranged in this survey, all of which were installed after secondary reaming of the coring hole (Figure 5). The depth of coring in holes 192K11 and $192 \mathrm{~K} 12$ is $60 \mathrm{~m}$, and double-U-shaped PE pipe heat exchangers of $54 \mathrm{~m}$ and $60 \mathrm{~m}$ are installed, respectively. Besides, the depth of coring in holes 192K13 and 192K14 is $100 \mathrm{~m}$, and $100 \mathrm{~m}$ double-U-shaped PE pipe heat exchangers are installed. The PE pipe should be left about $1 \mathrm{~m}$ long on the ground considering the need of connecting the thermal response test instrument.

\subsection{Thermal Response Test}

3.2.1. Introduction to the Test. The main performance parameters of the equipment (Figure 6) which is self- 

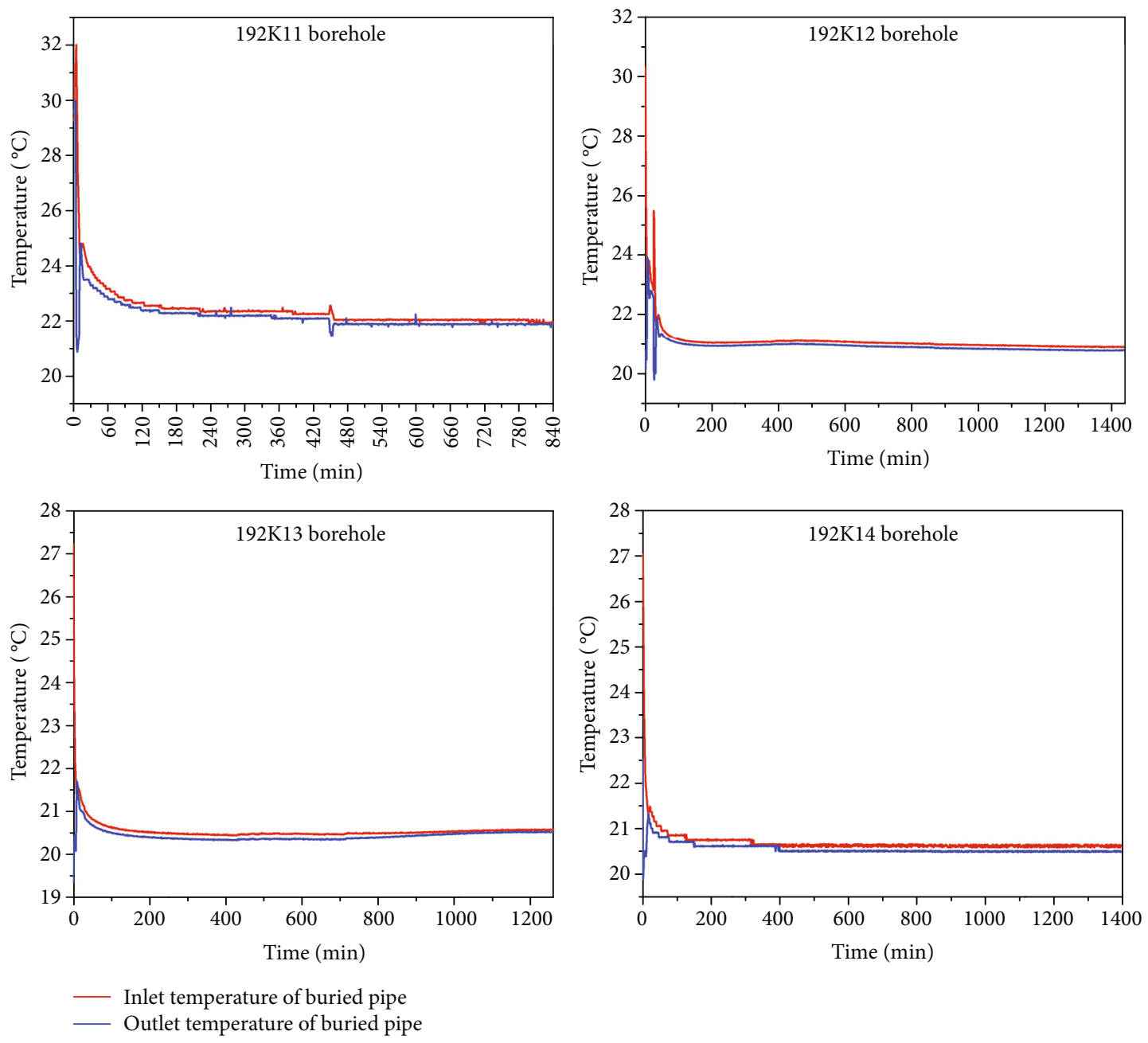

Figure 7: Initial average temperature of the rock-soil body in 4 geothermal test holes.

developed named FTPT11 for field thermal response test are shown in Table 1 . The test equipment is mainly composed of a heat pump system, electric heater, water-replenishing tank, circulating pump, circulating pipeline, temperature and flow detection elements, etc. The flow meter is installed at the water supply pipe of the vertical buried pipe, and the temperature detection points are arranged at the water supply pipe, return pipe, and circulating pipe, which is used to automatically record the flow and temperature of circulating water in the pipe.

Four groups of thermal response tests have been completed in this exploration, and each group includes the initial mean ground temperature test (case 1), high-power constant heat flux test (case 2), low-power constant heat flux test (case 3 ), simulated constant temperature test in summer (case 4), and simulated constant temperature test in winter (case 5).

The purpose of the low-power constant heat flux test and high-power constant heat flux test is to obtain the comprehensive thermal conductivity of the rock-soil body in the depth range of the vertical heat exchanger. The purpose of the simulated constant temperature test in summer and simulated constant temperature test in winter is to obtain the heat transfer power per meter length of the vertically buried tube heat exchanger under specific heat transfer conditions. Combined with the initial average ground temperature test results, the relationship between heat transfer power per unit length and medium temperature of vertical heat exchanger is further fitted, and the effective heat transfer coefficient of vertically buried tube heat exchanger is obtained.

\subsubsection{Results and Analysis}

(1) The Initial Average Temperature of the Rock-Soil Body (Case 1). Figure 7 shows the test curve of the average initial temperature of the rock-soil body in the four geothermal holes. After a certain period of system circulation, the final stable average water temperature (initial average temperature of the rock-soil body) at the outlet of four test holes is $21.9^{\circ} \mathrm{C}, 20.8^{\circ} \mathrm{C}, 20.5^{\circ} \mathrm{C}$, and $20.5^{\circ} \mathrm{C}$, respectively.

(2) High- and Low-Power Constant Heat Flux Test (Case 2 and Case 3). The test duration, heating power, and flow rate of each test hole are $48 \mathrm{~h}, 1.910 \mathrm{~kW}$, and $1.117 \mathrm{~m}^{3} / \mathrm{h}$, respectively, in the low-power constant heat flux test. According to the test data, the curve of the temperature at the inlet and outlet of the buried pipe with time is drawn as shown in 

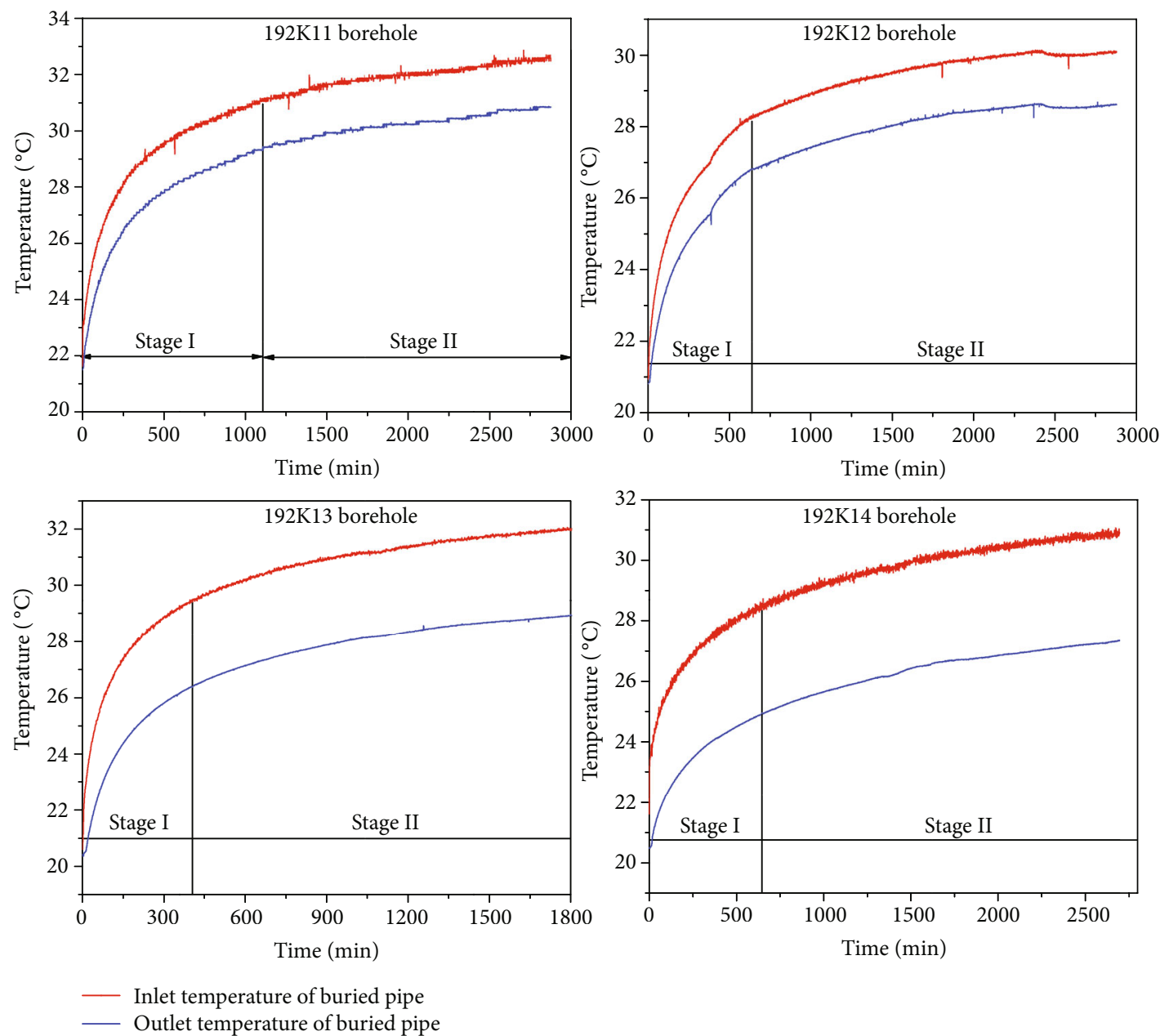

FIGURE 8: Results of low-power constant heat flux test in four geothermal holes.

Figure 8. Each temperature measurement curve can be divided into two obvious stages: rapid temperature rise (stage I) and stable temperature (stage II). Stage I is in the first ten hours of the test, the temperature at the inlet and outlet of the buried pipe changes rapidly, and the temperature in the borehole (backfill material) rises rapidly. Stage II shows that the temperature change in the borehole decreases with the heating time, which can be regarded as a steady-state heat conduction process.

The linear source model proposed by Hellström [16] is selected to calculate the thermal conductivity. The mean temperature of the circulating medium at time $\tau$ can be expressed as follows:

$$
T_{\mathrm{f}}=T_{\mathrm{ff}}+q_{\mathrm{l}} \cdot\left[R_{\mathrm{b}}+\frac{1}{4 \pi \lambda_{\mathrm{s}}} \cdot E i\left(\frac{d_{\mathrm{b}}^{2} \rho_{\mathrm{s}} c_{\mathrm{s}}}{16 \lambda_{\mathrm{s}} \tau}\right)\right],
$$

where $T_{\mathrm{f}}$ is the mean temperature of circulating medium $\left({ }^{\circ} \mathrm{C}\right), T_{\mathrm{ff}}$ is the undisturbed ground temperature $\left({ }^{\circ} \mathrm{C}\right), q_{1}$ is the heat flux per length $(\mathrm{W}), \rho_{\mathrm{s}}$ is the mean density of the ground surrounding the BHE $\left(\mathrm{kg} / \mathrm{m}^{3}\right), \tau$ is the time $(\mathrm{s}), c_{\mathrm{s}}$ is the mean specific heat capacity of the ground surrounding the BHE $(\mathrm{J} /(\mathrm{kg} \mathrm{K})), d_{\mathrm{b}}$ is the borehole diameter $(\mathrm{m})$, and $\lambda_{\mathrm{s}}$ is the thermal conductivity of the ground surrounding the borehole $(\mathrm{W} /(\mathrm{m} \mathrm{K}))$.

When the heating time is sufficiently long, the following equation is obtained:

$$
\operatorname{Ei}\left(\frac{d_{\mathrm{b}}^{2} \rho_{\mathrm{s}} c_{\mathrm{s}}}{16 \lambda_{\mathrm{s}} \tau}\right) \approx \ln \left(\frac{16 \lambda_{\mathrm{s}} \tau}{d_{\mathrm{b}}^{2} \rho_{\mathrm{s}} c_{\mathrm{s}}}\right)-\gamma
$$

Linear regression is presented between the borehole wall temperature and logarithmic time. Equation (4) can be simplified to

$$
T_{\mathrm{f}}=m \ln (t)+n,
$$

where $m$ is the slope of the linear regression between temperature and logarithmic time.

The equations determine the heat exchange between the circulating medium and the surrounding ground. Thus, the ground thermal conductivity $\lambda_{\mathrm{s}}$ can be determined. According to the test data of the temperature stable section of each test hole, the curve of constant heat flow heating $T_{\mathrm{f}}$ versus $\ln (t)$ of each test hole is drawn as Figure 9. 

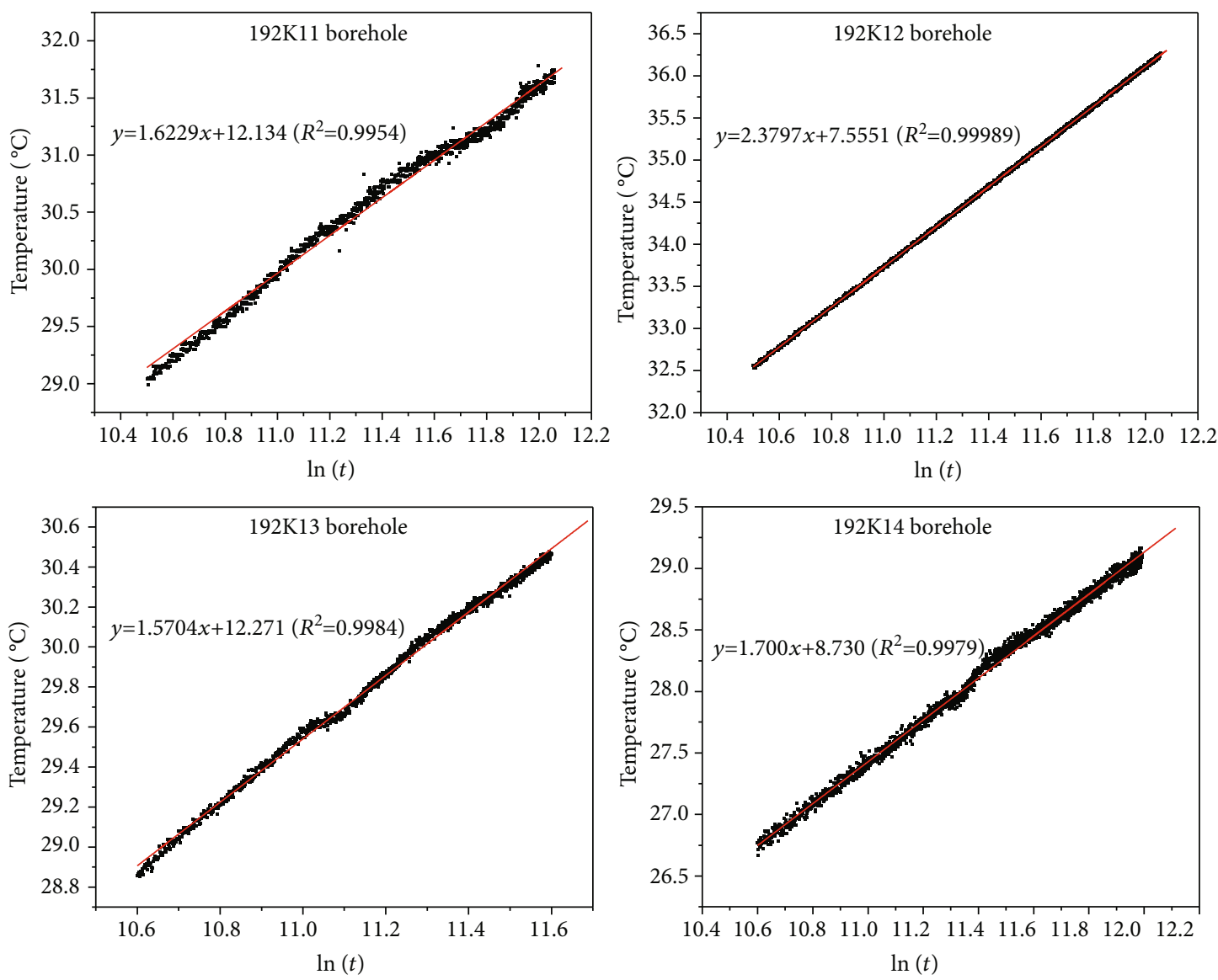

FIgURE 9: The variation curve of low-power constant heat flow heating $T_{\mathrm{f}}$ with $\ln (t)$ in four geothermal test holes.

The test duration, heating power, and flow rate of each test hole are $48 \mathrm{~h}, 3.725 \mathrm{~kW}$, and $1.046 \mathrm{~m}^{3} / \mathrm{h}$, respectively, in the high-power constant heat flux test. According to the test data, draw the curve of the temperature at the inlet and outlet of the buried pipe with time, as shown in Figure 10. It can be seen from the curve that the shape of the curve is basically the same as that of the low-power constant heat flow test. In the first ten hours, the temperature changes at the inlet and outlet of the buried pipe are relatively fast, and the temperature rises rapidly in the borehole (backfill material). With continuous heating, the range of temperature change is reduced in the hole decreases, and the heat transfer process in the hole is similar to the steady-state heat conduction process.

According to the test data of the temperature stable section of each test hole, the curve of constant heat flow heating $T_{\mathrm{f}}$ with $\ln (t)$ is drawn in Figure 11, and the average thermal conductivity of the rock-soil body is calculated.

In conclusion, the average thermal conductivity of the rock-soil body at the four exploration holes (Table 2) is calculated based on the results of the high-power and lowpower constant heat flow test, so as to predict the effect of geothermal exploitation in the study area more accurately. The results show that the average thermal conductivity of $\mathrm{K} 11$ and $\mathrm{K} 12$ is close, while the value of K13 and K14 is close. This is because the holes $\mathrm{K} 11$ and $\mathrm{K} 12$ are near while holes K13 and K14 are near, and the difference of lithology between adjacent boreholes is small.

(3) Simulated Constant Temperature Test in Summer and Winter (Case 4 and Case 5). Because the ground source heat pump project is used for cooling in summer and heating in winter in the study area, it is necessary to test the operation effect of the heat pump system under reservoir conditions in the early stage of the construction. The variation of the temperature at the inlet and outlet of the buried pipe with time in the simulated winter and summer conditions of the four geothermal wells is shown in Figure 12. Among them, the simulation test time, the water supply temperature, and the flow rate are $24 \mathrm{~h}, 38.94^{\circ} \mathrm{C}$, and $1.28 \mathrm{~m}^{3} / \mathrm{h}$, respectively, in summer, while those are $50 \mathrm{~h}, 7.04^{\circ} \mathrm{C}$, and $1.22 \mathrm{~m}^{3} / \mathrm{h}$ in winter. In the later stage of the test, the temperature and heat transfer at the inlet and outlet of the buried pipe are basically stable, which shows that the simulation test time meets the requirements. According to equation (2), the data within $12 \sim 24 \mathrm{~h}$ after the temperature curve reaches stable are taken to calculate the heat injection and extraction per unit of specific hole location.

According to the results of case 1 , case 4 , and case 5 , the relationship curve between heat transfer $q$ with the average temperature $T_{\mathrm{f}}$ is determined, as shown in Figure 13(a). 

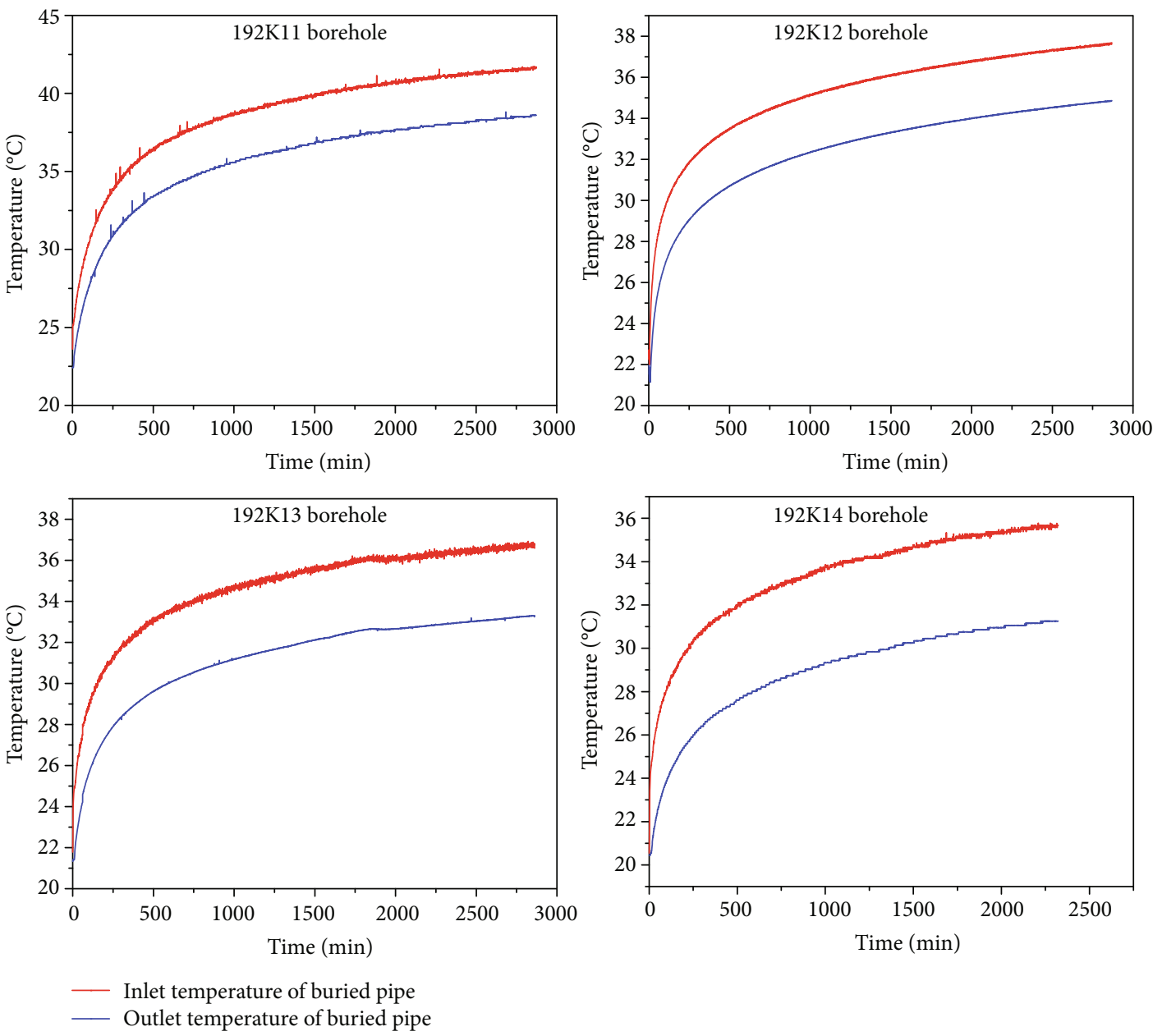

FIgURE 10: Results of high-power constant heat flux test in four geothermal holes.

The single-hole heat transfer under different working conditions is further deduced based on the curve, which is shown in Figure 13(b). Among them, the temperature conditions of supply and return water under simulated winter and summer conditions are shown in Table 3.

(1) Test Results. Based on the test data of the above holes, the average thermal conductivity, the heat injection, and extraction of each hole are calculated, as shown in Table 4 . Therefore, the heat injection and extraction per unit of double- $U$ heat exchanger in the shallow hole $(54 \mathrm{~m} \sim 60 \mathrm{~m})$ and deep hole $(100 \mathrm{~m})$ are $37.9(\mathrm{~W} / \mathrm{m}), 48.1(\mathrm{~W} / \mathrm{m}), 43.7(\mathrm{~W} / \mathrm{m})$, and $51.3(\mathrm{~W} / \mathrm{m})$, respectively. The heat removal capacity and heat recovery capacity of the double- $U$ heat exchanger in the deep hole have increased $15.3 \%$ and $6.7 \%$ higher, respectively, comparing the double- $U$ heat exchanger in a shallow hole.

\section{Development Potential of Shallow Geothermal Energy in the Study Area}

4.1. Limitation of Development Conditions of Shallow Geothermal Energy. The vertical ground source heat pump system can provide cooling in summer and heating in winter.
The underground heat transfer power in summer and winter, respectively, refers to the heat transfer power emitted to the soil in summer and absorbed from soil in winter. Taking a building of one hundred thousand square meters as an example, assuming that the cooling load in summer is $80 \mathrm{~W} / \mathrm{m}$ and the heating load in winter is $40 \mathrm{~W} / \mathrm{m}$ when the ground source heat pump project adopts a double-U-type heat exchanger for 100 meters, the cooling and heating load is $8000 \mathrm{~kW}$ and $4000 \mathrm{~kW}$, respectively. The underground heat transfer power $Q_{1}^{\prime}$ and $Q_{2}^{\prime}$ in summer and winter can be calculated by the following formula, respectively:

$$
\begin{gathered}
Q_{1}{ }^{\prime}=Q_{1} \times\left(1+\frac{1}{\mathrm{COP}_{1}}\right), \\
Q_{2}{ }^{\prime}=Q_{2} \times\left(1-\frac{1}{\mathrm{COP}_{2}}\right),
\end{gathered}
$$

where $Q_{1}^{\prime}$ is the heat transfer power discharged to soil in summer $(\mathrm{kW}) ; Q_{1}$ is the total cooling load at the end of air conditioning in summer $(\mathrm{kW}) ; Q_{2}^{\prime}$ is the heat transfer power absorbed from soil in winter $(\mathrm{kW}) ; Q_{2}$ is the total heat load at the end of air conditioning in winter $(\mathrm{kW})$; 

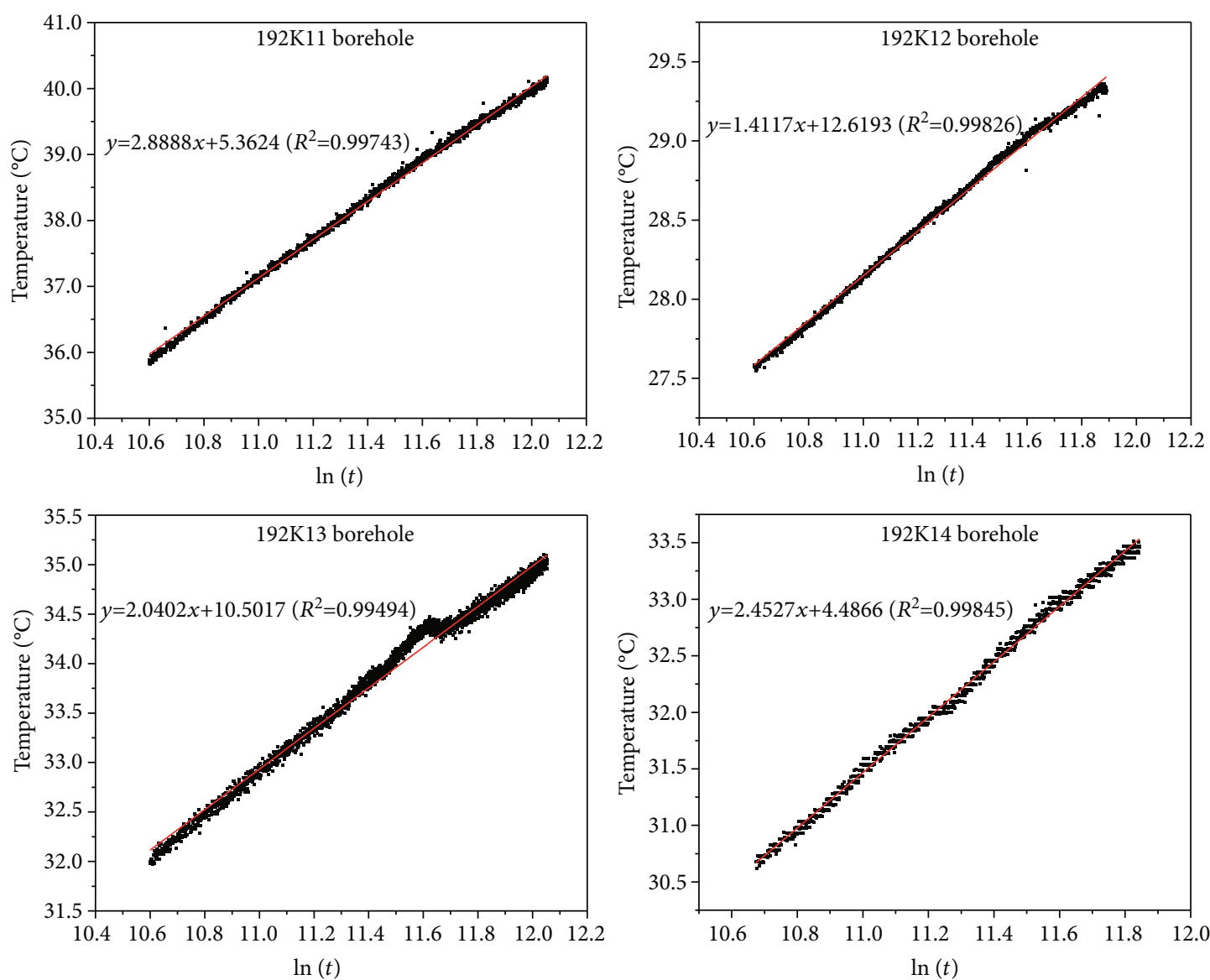

FIGURE 11: The variation curve of high-power constant heat flow heating $T_{\mathrm{f}}$ with $\ln (t)$ in four geothermal test holes.

TABLE 2: Average thermal conductivity of rock-soil body under the high- and low-power constant heat flux test.

\begin{tabular}{lcccc}
\hline Test type & $192 \mathrm{~K} 11$ & $192 \mathrm{~K} 12$ & $192 \mathrm{~K} 13$ & $192 \mathrm{~K} 14$ \\
\hline Low-power constant heat & $1.93 \mathrm{~W} /\left(\mathrm{m} \cdot{ }^{\circ} \mathrm{C}\right)$ & $1.80 \mathrm{~W} /\left(\mathrm{m} \cdot{ }^{\circ} \mathrm{C}\right)$ & $2.04 \mathrm{~W} /\left(\mathrm{m} \cdot{ }^{\circ} \mathrm{C}\right)$ & $2.10 \mathrm{~W} /\left(\mathrm{m} \cdot{ }^{\circ} \mathrm{C}\right)$ \\
High-power constant heat & $1.90 \mathrm{~W} /\left(\mathrm{m} \cdot{ }^{\circ} \mathrm{C}\right)$ & $1.80 \mathrm{~W} /\left(\mathrm{m} \cdot{ }^{\circ} \mathrm{C}\right)$ & $2.08 \mathrm{~W} /\left(\mathrm{m} \cdot{ }^{\circ} \mathrm{C}\right)$ & $2.08 \mathrm{~W} /\left(\mathrm{m} \cdot{ }^{\circ} \mathrm{C}\right)$ \\
\hline
\end{tabular}

$\mathrm{COP}_{1}$ is the refrigeration coefficient of water source heat pump unit under design condition; the value is 5.4 ; and $\mathrm{COP}_{2}$ is the heating coefficient of water source heat pump unit under design condition; the value is 4.3. According to the results, by calculating equations (4) and (5), it can be seen that the summer heat removal power should be $9481 \mathrm{~kW}$, and the winter heat extraction power is $3070 \mathrm{~kW}$, so as to meet the design target.

4.2. Layout of Geothermal Well. According to the results of various hot holes presented in Table 4 , it can be seen that the heat transfer capacity of a double- $U$ heat exchanger in the shallow hole $(54 \mathrm{~m} \sim 60 \mathrm{~m})$ is lower than that of the deep hole $(100 \mathrm{~m})$. Considering the need to reduce the floor area of a vertically buried pipe heat exchanger by improving the heat exchange capacity or the heat exchange capacity of the single hole, it is recommended to use a $100 \mathrm{~m}$ double-U-type heat exchanger in the later ground source heat pump project. Therefore, in order to meet the demand of cooling and heating if the cooling and heating load is calculated as $8000 \mathrm{~kW}$ and $4000 \mathrm{~kW}$, respectively, of a building with an area of one hundred thousand square meters, the number of heat source wells to be arranged is shown in Table 5. To meet the heating and cooling requirements of the target area, about 2170 similar geothermal wells are required to operate in summer, while at least 600 geothermal wells are required to operate at the same time in winter.

The heating system runs for 90 days in winter and 18 hours a day. In summer, the refrigeration system operates for 120 days and 12 hours a day, and the load factor is 0.75 in winter and summer.

The accumulated heat discharge in summer is $Q_{1}=$ $9481 \times 12 \times 120 \times 0.75 \times 3.6 / 1000=36862 \mathrm{GJ}$.

The accumulated heat discharge in winter is $Q_{2}=$ $3070 \times 18 \times 90 \times 0.75 \times 3.6 / 1000=13428 \mathrm{GJ}$. 

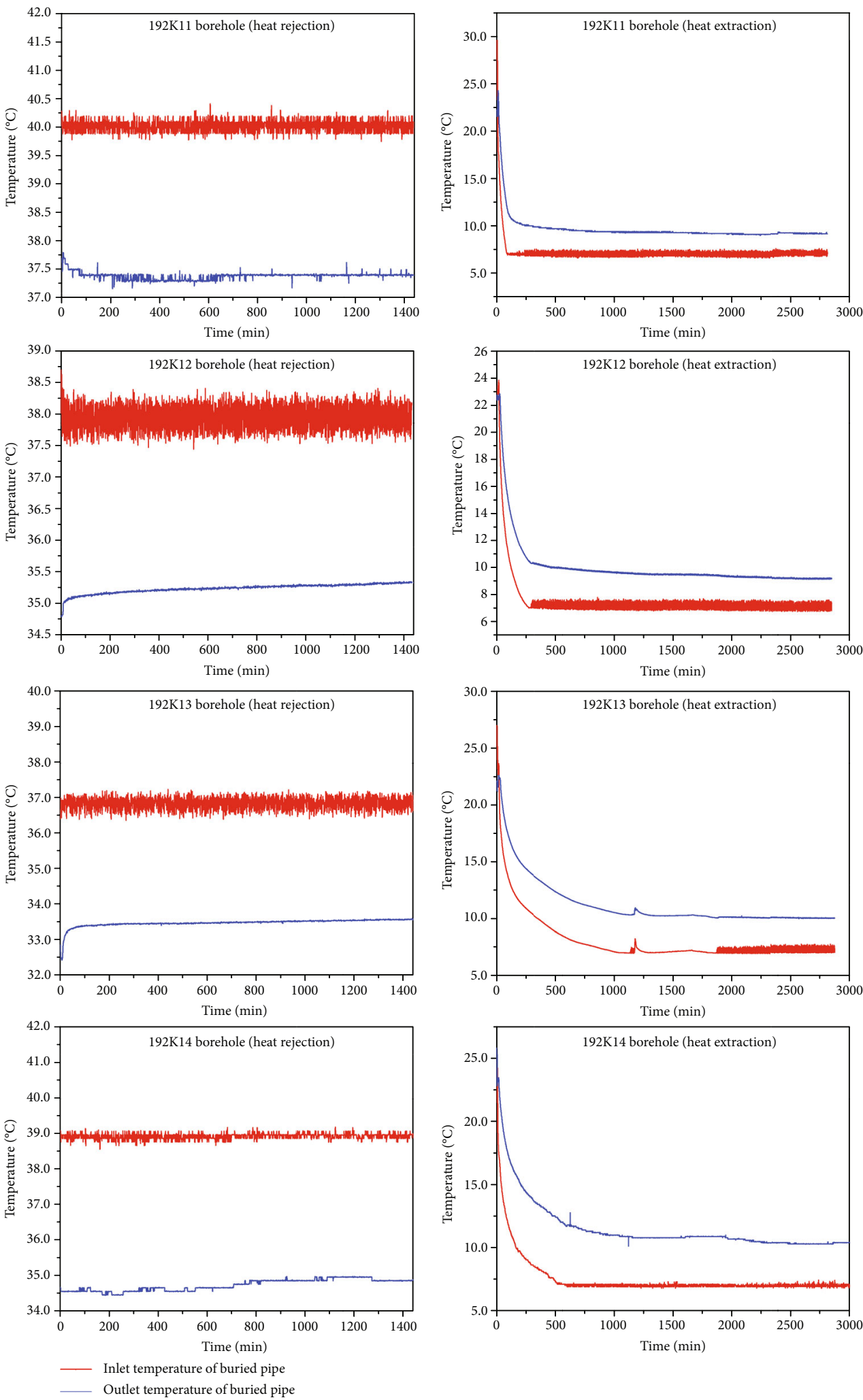

FIgURE 12: The variation of temperature with time of four geothermal holes under Case 4 and Case 5. 


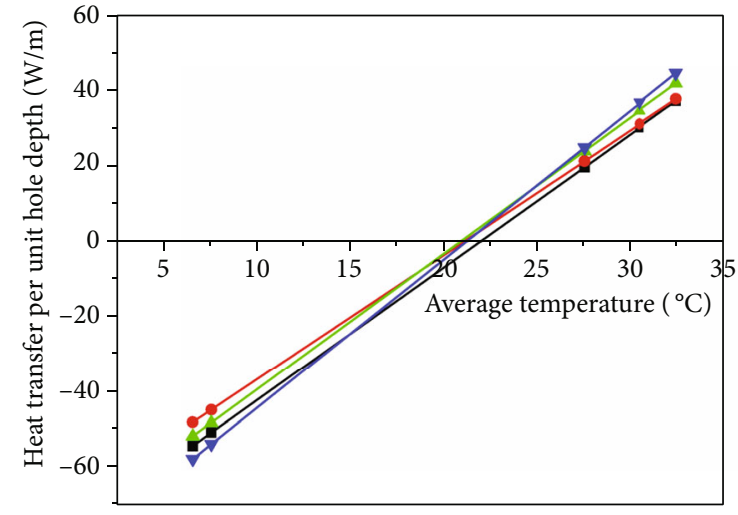

(a)

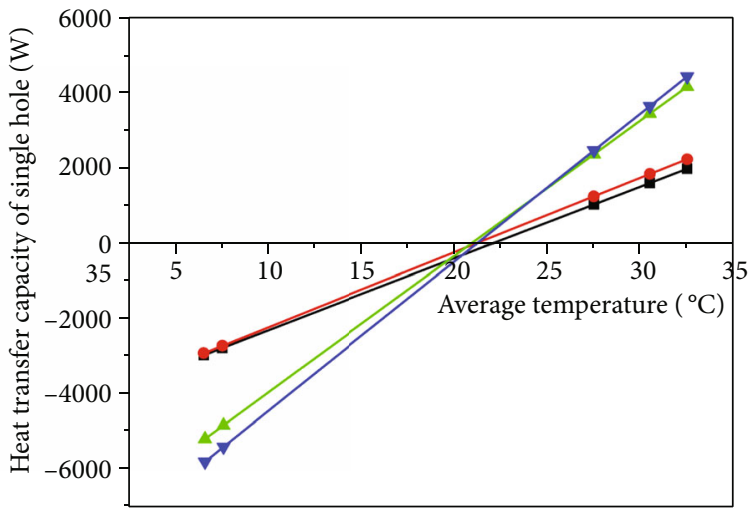

(b)

$\rightarrow 192 \mathrm{~K} 11 \rightarrow 192 \mathrm{~K} 13$

FIGURE 13: Relationship between the average temperature of supply water and heat transfer per unit hole depth of four test holes (a) and the relationship between the average temperature of supply water and single-hole heat transfer of four test holes (b). Note: “-” means taking heat from underground.

TABLE 3: The temperature conditions of supply and return water under simulated winter and summer conditions.

\begin{tabular}{lccc}
\hline Conditions & $\begin{array}{c}\text { The temperature of supply } \\
\text { water }\left({ }^{\circ} \mathrm{C}\right)\end{array}$ & $\begin{array}{c}\text { The temperature of return } \\
\text { water }\left({ }^{\circ} \mathrm{C}\right)\end{array}$ & $\begin{array}{c}\text { The average temperature of supply and } \\
\text { return water }\left({ }^{\circ} \mathrm{C}\right)\end{array}$ \\
\hline \multirow{3}{*}{ Summer } & 35 & 30 & 32.5 \\
& 33 & 28 & 30.5 \\
& 30 & 25 & 27.5 \\
\multirow{2}{*}{ Winter } & 5 & 10 & 7.5 \\
& 5 & 8 & 6.5 \\
\hline
\end{tabular}

TABLE 4: Test results of each test hole.

\begin{tabular}{|c|c|c|c|c|c|c|c|c|}
\hline Name & $\begin{array}{l}\text { Depth } \\
(\mathrm{m})\end{array}$ & $\begin{array}{l}\text { Backfill } \\
\text { method }\end{array}$ & $\begin{array}{c}\text { Initial } \\
\text { temperature } \\
\left({ }^{\circ} \mathrm{C}\right)\end{array}$ & $\begin{array}{l}\text { Low-power } \\
\text { thermal } \\
\text { conductivity } \\
\left(\mathrm{W} / \mathrm{m} \cdot{ }^{\circ} \mathrm{C}\right)\end{array}$ & $\begin{array}{l}\text { High-power } \\
\text { thermal } \\
\text { conductivity } \\
\left(\mathrm{W} / \mathrm{m} \cdot{ }^{\circ} \mathrm{C}\right)\end{array}$ & $\begin{array}{l}\text { Average power } \\
\text { thermal } \\
\text { conductivity } \\
\left(\mathrm{W} / \mathrm{m} \cdot{ }^{\circ} \mathrm{C}\right)\end{array}$ & $\begin{array}{l}\text { The reference value } \\
\text { of heat discharge } \\
(\mathrm{W} / \mathrm{m})\end{array}$ & $\begin{array}{c}\text { The reference value } \\
\text { of calorific } \\
\text { value }(\mathrm{W} / \mathrm{m})\end{array}$ \\
\hline $192 \mathrm{~K} 11$ & 54 & $\begin{array}{c}\text { Bottom-up } \\
\text { grouting }\end{array}$ & 21.9 & 1.93 & 1.90 & 1.92 & 37.6 & -51.1 \\
\hline $192 \mathrm{~K} 12$ & 60 & $\begin{array}{l}\text { Bottom-up } \\
\text { grouting }\end{array}$ & 20.8 & 1.80 & 1.80 & 1.80 & 38.1 & -45.0 \\
\hline $192 \mathrm{~K} 13$ & 100 & $\begin{array}{l}\text { Bottom-up } \\
\text { grouting }\end{array}$ & 20.5 & 2.04 & 2.08 & 2.06 & 42.3 & -48.4 \\
\hline $192 \mathrm{~K} 14$ & 100 & $\begin{array}{l}\text { Bottom-up } \\
\text { grouting }\end{array}$ & 20.5 & 2.10 & 2.08 & 2.09 & 45.0 & -54.2 \\
\hline
\end{tabular}

TABLE 5: Number of heat source wells required for a building with an area of one hundred thousand square meters.

\begin{tabular}{lccccccc}
\hline $\begin{array}{l}\text { Cooling load } \\
\text { in summer } \\
(\mathrm{kW})\end{array}$ & $\begin{array}{c}\text { Heat load in } \\
\text { winter }(\mathrm{kW})\end{array}$ & $\begin{array}{c}\text { Heat } \\
\text { removal } \\
\text { power }(\mathrm{kW})\end{array}$ & $\begin{array}{c}\text { Heating } \\
\text { extraction } \\
\text { power }(\mathrm{kW})\end{array}$ & $\begin{array}{c}\text { Heat removal in } \\
\text { single hole }(\mathrm{kW})\end{array}$ & $\begin{array}{c}\text { Heat extraction } \\
\text { in single hole } \\
(\mathrm{kW})\end{array}$ & $\begin{array}{c}\text { Number of wells } \\
\text { required in } \\
\text { summer }\end{array}$ & $\begin{array}{c}\text { Number of wells } \\
\text { required in } \\
\text { winter }\end{array}$ \\
\hline 8000 & 4000 & 9481 & 3070 & 4.37 & 5.13 & 2170 \\
\hline
\end{tabular}


TABLE 6: Energy cost of different heating modes.

\begin{tabular}{|c|c|c|c|c|c|}
\hline Type & Price & Consumption & $\begin{array}{l}\text { Cost } \\
\text { (yuan) }\end{array}$ & $\begin{array}{l}\text { Energy cost per square } \\
\text { meter }\left(\text { yuan } / \mathrm{m}^{2}\right)\end{array}$ & Remarks \\
\hline Electricity & 0.8 (yuan/kWh) & $4860000(\mathrm{kWh})$ & 3888000 & 38.9 & Thermal efficiency is 1 \\
\hline Coal & 600 (yuan/kg) & $1116172(\mathrm{~kg})$ & 669703 & 6.7 & Thermal efficiency is 0.75 \\
\hline Natural gas & $3\left(\right.$ yuan $\left./ \mathrm{m}^{3}\right)$ & $607500\left(\mathrm{Nm}^{3}\right)$ & 1822500 & 18.2 & Thermal efficiency is 0.8 \\
\hline $\begin{array}{l}\text { Central air-conditioning } \\
\text { (CAC) }\end{array}$ & 0.8 (yuan/kWh) & $2113043(\mathrm{kWh})$ & 1690430 & 16.9 & Comprehensive energy efficiency is 2.3 \\
\hline $\begin{array}{l}\text { Ground source heat } \\
\text { pump (GSHP) }\end{array}$ & 0.8 (yuan/kWh) & $1472727(\mathrm{kWh})$ & 1178180 & 11.8 & Comprehensive energy efficiency is 3.3 \\
\hline
\end{tabular}

Remarks: electricity price is 0.8 yuan $/ \mathrm{kWh}$. Natural gas price is $3.0 \mathrm{yuan} / \mathrm{m}^{3}$, and its calorific value is $36.0 \mathrm{MJ} / \mathrm{m}^{3}$. The calorific value of coal is $20.9 \mathrm{MJ} / \mathrm{kg}$. The heating season is 90 days, and the average load rate is 0.75 .

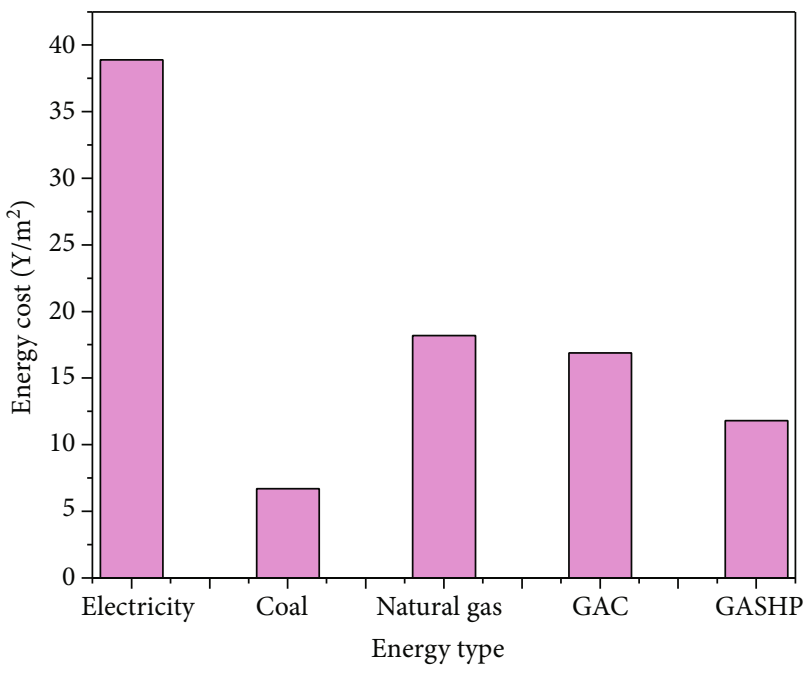

Figure 14: Heating cost of various energy sources.

\section{Economic and Environmental Benefits}

5.1. Economic Evaluation. The operating economy of the ground source heat pump can be indirectly reflected by the energy consumption cost. Table 6 shows the comparison of the costs of pure electric heating; boiler heating by coal fire, oil fire, and gas fire; traditional central air conditioning (dual-use cooling and heating); and ground source heat pump heating. From the perspective of energy conversion, $1 \mathrm{kWh}$ electric energy can only produce $1 \mathrm{kWh}$ of heat energy, and the thermal efficiency of a gas-fired boiler is only $70 \% \sim 90 \%$, which means it needs $4000 \sim 5143 \mathrm{~kJ}$ to produce the same heat. The traditional central air conditioning system in which COP is about 2.2 2.3 only needs $1565 \sim 1636 \mathrm{~kJ}$ energy to produce the same heat while $857 \sim 1091 \mathrm{~kJ}$ heat is needed to produce the same heat by the ground source heat pump air conditioning system in which COP is about 3.3 4.2.

Suppose the heating area of the building is one hundred thousand square meters, and the total heat load in winter is $4000 \mathrm{~kW}$. Taking the average load rate of the whole heating season as 0.75 , the total heat demand in the heating season
TABLE 7: The reference coefficient of converting various energy into standard coal.

\begin{tabular}{lcc}
\hline Name & The reference coefficient & Mean calorific value \\
\hline Raw coal & $0.7143 \mathrm{kgce} / \mathrm{kg}$ & $20908 \mathrm{~kJ} / \mathrm{kg}$ \\
$\begin{array}{l}\text { Thermal power } \\
\text { (equivalent value) }\end{array}$ & $/$ & $0.03412 \mathrm{kgce} / \mathrm{MJ}$ \\
\hline
\end{tabular}

is $17496(\mathrm{GJ})$. On this basis, the energy costs of different heating modes are calculated as shown in Table 6.

Comparing energy cost per square meter which is shown in Figure 14, the cost of using coal-fired boiler is the lowest, followed by ground source heat pump, gas-fired boiler, central air conditioning, and electric heating. However, the coal-fired boiler will make the environmental pollution more serious by producing air pollutants and solid waste pollutants. The energy cost per square meter of the ground source heat pump is the lowest of the other three methods, and it is very good to protect the environment. At the same time, the ground source heat pump is a cold and heat source type in line with the national energy development direction, which can not only heat but also cool. Compared with other cold and heat source types, it should be vigorously promoted because of its obvious energy conservation.

5.2. Environmental Benefit. The environmental evaluation is carried out. Table 7 shows the reference coefficient of converting various energy into standard coal, and the standard coal quantity $(M)$ saved by using shallow geothermal energy to replace traditional coal for heating in winter is evaluated.

Based on the data of saving standard coal $(M)$ calculated by formula (6), the social and environmental benefits brought from coal saving under the same calorific value are evaluated. The calculation of emission reduction and treatment cost saving of air pollutants and solid wastes from coal combustion is shown in Table 8.

$$
M=\frac{\sum W_{t}}{4.1868 / 7} .
$$

Suppose the heating area of the building is one hundred thousand square meters and the heating load is $4000 \mathrm{~kW}$, the 
TABle 8: Pollutant emission reduction and cost-saving.

\begin{tabular}{lccccccc}
\hline Item & & $\mathrm{CO}_{2}$ & $\mathrm{SO}_{2}$ & $\mathrm{NOx}$ & Suspended dust & Coal ash residue \\
\hline \multirow{2}{*}{ Reduction } & Unit & $\mathrm{t} / \mathrm{a}$ & $\mathrm{t} / \mathrm{a}$ & $\mathrm{t} / \mathrm{a}$ & $\mathrm{t} / \mathrm{a}$ & $\mathrm{t} / \mathrm{a}$ & $(3)=0.8 \% \mathrm{M}$ \\
& Formula & $(1)=2.386 \mathrm{M}$ & $(2)=1.7 \% \mathrm{M}$ & $(3)=0.6 \% \mathrm{M}$ & $(5)=0.1 \mathrm{M}$ \\
\hline \multirow{2}{*}{ Cost } & Unit & Ten thousand yuan & Ten thousand yuan & Ten thousand yuan & Ten thousand yuan & $/$ \\
& Formula & 0.1 yuan $/ \mathrm{kg}$ & 1.1 yuan $/ \mathrm{kg}$ & 2.4 yuan $/ \mathrm{kg}$ & 0.8 yuan $/ \mathrm{kg}$ & Freight costs \\
\hline
\end{tabular}

TABLE 9: Evaluation results of saving standard coal.

\begin{tabular}{lccc}
\hline Project & Heating load in winter $(\mathrm{kW})$ & Heat requirement for heating in winter $(\mathrm{GJ})$ & Saving standard coal $(\mathrm{t})$ \\
\hline Heating & 4000 & 17496 & 597 \\
\hline
\end{tabular}

TABLE 10: Evaluation results of emission reduction and cost-saving.

\begin{tabular}{lccccc}
\hline Item & $\mathrm{CO}_{2}$ & $\mathrm{SO}_{2}$ & $\mathrm{NOx}$ & Suspended dust & Coal ash residue \\
\hline Reduction (t/a) & 1424 & 10.1 & 3.6 & 4.8 & 59.7 \\
Cost (ten thousand yuan/a) & 14.2 & 1.11 & 0.86 & 0.38 & Freight costs \\
\hline
\end{tabular}

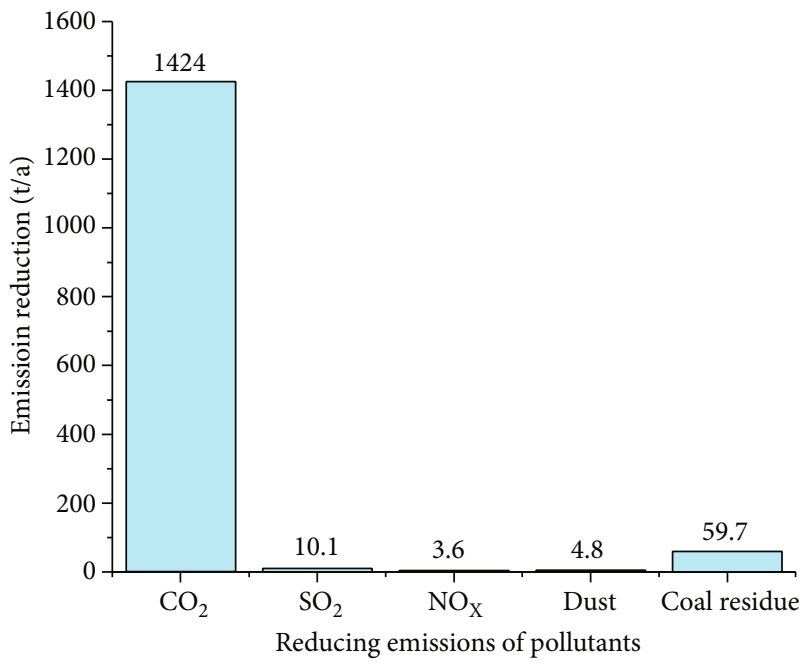

FIGURE 15: Reducing emissions of pollutants.

evaluation results of environmental benefits brought by the development and utilization of shallow geothermal energy for heating in winter are shown in Tables 9 and 10 .

It can be seen that the development and utilization of shallow geothermal energy resources for winter heating instead of conventional energy can reduce 59.7 tons of solid waste ash and the emission of 1442.5 tons of air pollutants such as carbon dioxide, sulfur dioxide, nitrogen oxides, and suspended dust every year when the heating area of the building is one hundred thousand square meters. Therefore, 166000 yuan can be saved on the environmental treatment (Figure 15).

\section{Conclusions}

Based on the analysis and calculation of the above test results, the following conclusions can be obtained, which can provide the basis for the later engineering construction:
(1) The initial average temperature of the shallow strata from $54 \mathrm{~m}$ to $60 \mathrm{~m}$ in the study area is $20.9^{\circ} \mathrm{C} 21.9^{\circ} \mathrm{C}$. The average comprehensive thermal conductivity (average results of high- and lowpower tests) of the strata is $1.80 \sim 1.92 \mathrm{~W} /\left(\mathrm{m} .{ }^{\circ} \mathrm{C}\right)$. The initial average temperature of the layer shallower than $100 \mathrm{~m}$ is about $20.5^{\circ} \mathrm{C}$, and the average comprehensive thermal conductivity (average results of high- and low-power tests) of the rock-soil body in this layer is $2.06 \sim 2.09 \mathrm{w} /\left(\mathrm{m} \cdot{ }^{\circ} \mathrm{C}\right)$

(2) The heat removal capacity and heat recovery capacity of the double- $U$ heat exchanger in the deep hole have increased $15.3 \%$ and $6.7 \%$ higher, respectively, comparing the double- $U$ heat exchanger in the shallow hole

(3) The energy cost per square meter of the ground source heat pump is 11.8 yuan for a building of one hundred thousand square meters which the heat removal power is expected to be $9481 \mathrm{~kW}$ in summer and $3070 \mathrm{~kW}$ in winter. And the annual emission of carbon dioxide, sulfur dioxide, nitrogen oxides, suspended dust, and other air pollutants to the atmosphere can be reduced by $1442.5 \mathrm{t}$, and the solid waste ash and slag can be reduced by $59.7 \mathrm{t}$. The annual environmental treatment cost will be saved by 166000 yuan

\section{Data Availability}

The data used to support the study are available within the article.

\section{Conflicts of Interest}

The authors declare no conflicts of interest. 


\section{References}

[1] W. Wang, J. Wang, Y. Luo, and Y. Zhang, “Assessment of three types of shallow geothermal resources and groundsource heat-pump applications in provincial capitals in the Yangtze River Basin, China," Renewable and Sustainable Energy Reviews, vol. 111, pp. 392-421, 2019.

[2] R. M. Singh, A. K. Sani, and T. Amis, "An overview of groundsource heat pump technology," in Managing Global Warming, pp. 455-485, Elsevier Ltd, 2019.

[3] W. Xu, China Ground Source Heat Pump Development Research Report (2018), China Architecture \& Building Press, 2019.

[4] K. Zhou, J. Mao, Y. Li, and H. Zhang, "Performance assessment and techno-economic optimization of ground source heat pump for residential heating and cooling: a case study of Nanjing, China," Sustainable Energy Technologies and Assessments, vol. 40, article 100782, 2020.

[5] H. Esen, M. Inalli, and M. Esen, "A techno-economic comparison of ground-coupled and air-coupled heat pump system for space cooling," Building and Environment, vol. 42, no. 5, pp. 1955-1965, 2007.

[6] H. Esen, M. Inalli, M. Esen, and K. Pihtili, "Energy and exergy analysis of a ground-coupled heat pump system with two horizontal ground heat exchangers," Building and Environment, vol. 42, no. 10, pp. 3606-3615, 2007.

[7] H. Esen, M. Inalli, and M. Esen, "Technoeconomic appraisal of a ground source heat pump system for a heating season in eastern Turkey," Energy Conversion and Management, vol. 47, no. 9-10, pp. 1281-1297, 2006.

[8] G. Nouri, Y. Noorollahi, and H. Yousefi, "Designing and optimization of solar assisted ground source heat pump system to supply heating, cooling and hot water demands," Geothermics, vol. 82, pp. 212-231, 2019.

[9] A. Balbay and M. Esen, "Experimental investigation of using ground source heat pump system for snow melting on pavements and bridge decks," Scientific Research and Essays, vol. 5, pp. 3955-3966, 2010.

[10] A. Balbay and M. Esen, "Temperature distributions in pavement and bridge slabs heated by using vertical ground-source heat pump system," Acta Scientiarum-Technology, vol. 35, pp. 677-685, 2013.

[11] Q. Lu, G. A. Narsilio, G. R. Aditya, and I. W. Johnston, "Economic analysis of vertical ground source heat pump system in Melbourne," Energy, vol. 125, pp. 107-117, 2017.

[12] M. Esen and T. Yuksel, "Experimental evaluation of using various renewable energy sources for heating a greenhouse," Energy and Buildings, vol. 65, pp. 340-351, 2013.

[13] Q. Zhang, Y. Zhang, P. Gao, and Z. Yu, "Effect of natural cold source on groundwater source heat pump according to laboratory and field geotechnical thermal physical tests," Energy and Buildings, vol. 84, pp. 557-566, 2014.

[14] Y. Zhang, P. Gao, Z. Yu, J. Fang, and C. Li, "Characteristics of ground thermal properties in Harbin, China," Energy and Buildings, vol. 69, pp. 251-259, 2014.

[15] Y. Zhang, S. Hao, Z. Yu, J. Fang, J. Zhang, and X. Yu, "Comparison of test methods for shallow layered rock thermal conductivity between in situ distributed thermal response tests and laboratory test based on drilling in northeast China," Energy and Buildings, vol. 173, pp. 634-648, 2018.

[16] G. Hellström, "Ground heat storage: thermal analyses of duct storage system," Physics \& Astronomy, 1991.

[17] X. Zhang, E. Zhai, Y. Wu, D. Sun, and Y. Lu, "Theoretical and numerical analyses on hydro-thermal-salt-mechanical interaction of unsaturated salinized soil subjected to typical unidirectional freezing process," International Journal of Geomechanics, vol. 21, no. 7, article 04021104, 2021.

[18] C. Yavuzturk and J. D. Spitler, "Comparative study to investigate operating and control strategies for hybrid ground source heat pump sys-tems using a short time-step simulation model," ASHRAE Transactions, vol. 106, no. 2, pp. 192-209, 2000 . 